\author{
О. В. Криворучко, А. Г. Котов ${ }^{1}$ В. А. Самойлова, Е. Е. Котова ${ }^{1}$, В. М. Ковальов \\ НАЦІОНАЛЬНИЙ ФАРМАЦЕВТИЧНИЙ УНІВЕРСИТЕТ, ХАРКІВ \\ ДЕРЖАВНЕ ПІДПРИЕМСТВО “УКРӒ̈НСЬКИЙ НАУКОВИЙ ФАРМАКОПЕЙНИЙ ЦЕНТР \\ ЯКОСТІ ЛІКАРСЬКИХ ЗАСОБІВ"', ХАРКІВ
}

\title{
ВИЗНАЧЕННЯ ВМІСТУ АНТОЦІАНІВ I ТАНІНІВ У АРОНІї ЧОРНОПЛІДНОЇ ПЛОДАХ
}

Вступ. Аронія чорноплідна (Aronia melanocarpa) широко культивується в Україні як харчова, лікарська і декоративна рослина. Якість аронії чорноплідної плодів свіжих регламентувалася вимогами ФС 42-66-87 “Плоди аронії чорноплідної (горобини чорноплідної) свіжі”, проте статтю треба було переглянути з використанням сучасних підходів до стандартизації лікарської рослинної сировини.

Мета дослідження - визначити вміст антоціанів і танінів у аронії чорноплідної плодах свіжих та висушених для включення результатів досліджень до розділу монографрії "Кількісне визначення".

Методи дослідження. Вміст антоціанів і танінів в аронії чорноплідної плодах свіжих та висушених визначали методом абсорбційної спектрофотометрії.

Результати й обговорення. Вміст антоціанів у аронії чорноплідної плодах свіжих становить від $(0,45 \pm 0,01)$ до $(0,56 \pm 0,02) \%$ у перерахунку на чіанідин-3-О-глюкозиду хлорид, вміст танінів у аронії чорноплідної плодах висушених - від $(1,51 \pm 0,02)$ до $(2,41 \pm 0,03)$ \% у перерахунку на пірогалол і суху сировину. Тому до національної монографрії "Аронії (горобини) чорноплідної плоди свіжі"” запропоновано ввести показник: вміст антоціанів - не менше 0,40 \% у перерахунку на ціанідин-3-О-глюкозиду хлорид, а до національної монографрії “Аронії (горобини) чорноплідної плоди висушені" - показник: вміст танінів - не менше 1,5\% у перерахунку на пірогалол і суху сировину.

Висновок. Методом абсорбційної спектрофотометрії в аронії чорноплідної плодах свіжих визначено вміст антоціанів, у аронії чорноплідної плодах висушених - танінів. Результати досліджень використано при розробці національних монографрій “Аронії (горобини) чорноплідної плоди свіжі" й “Аронії (горобини) чорноплідної плоди висушені ${ }^{\text {”". }}$

КЛЮЧОВІ СЛОВА: аронія чорноплідна (Aronia melanocarpa); антоціани; таніни; поліфреноли; стандартизація.

ВСТУП. Аронія чорноплідна (Aronia melanосатра) з родини розові (Rosaceae) широко культивується в Україні як харчова, лікарська і декоративна рослина. Основними біологічно активними речовинами (БАР) аронії плодів $€$ фенольні сполуки, органічні кислоти, вуглеводи та вітаміни, які зумовлюють їх гіпотензивну, капілярозміцнювальну, антиоксидантну, протизапальну, сечогінну, урикозуричну, жовчогінну дію $[1,2]$. Якість аронії чорноплідної плодів свіжих регламентувалася вимогами ФС 42-66-87 “Плоди аронії чорноплідної (горобини чорноплідної) свіжі", проте статтю треба було переглянути 3 використанням сучасних підходів до стандартизації лікарської рослинної сировини [3]. Раніше ми вивчали проціанідини, карбонові кислоти,

(c) О. В. Криворучко, А. Г. Котов, В. А. Самойлова, Е. Е. Котова, В. М. Ковальов, 2018. терпеноїди аронії плодів [1, 4, 5]. Метою даного дослідження було визначити вміст антоціанів і танінів у аронії чорноплідної плодах свіжих та висушених для включення результатів досліджень до розділу монографії "Кількісне визначення". Для цього необхідно було провести аналіз певних серій сировини за уніфікованими методиками [6], описаними у ДФУ [7, 8].

МЕТОДИ ДОСЛІДЖЕННЯ. Дослідження аронії чорноплідної плодів свіжих проводили на 7 серіях зразків: RS 338 (номери зразків, що зареєстровані у ДП “Фармакопейний центр”) серія 010914 (фрармакопейна ділянка НФаУ, вересень 2014 р.); RS 339 - серія 020914 (м. Південний Харківської області, вересень 2014 р.); RS 340 - серія 030914 (м. Мерефра Харківської області, вересень 2014 р.); RS 341 - серія 040914 
(м. Чернігів, вересень 2014 р.); RS 342 - серія 050914 (м. Дергачі Харківської області, вересень 2014 р.); RS 343 - серія 060914 (с. Хорошево Харківської області, вересень 2014 р.); RS 344 серія 070914 (с. Циркуни Харківської області, вересень 2014 р.).

Дослідження аронії чорноплідної плодів висушених проводили на 7 серіях зразків: RS 345 серія 040913 (фрармакопейна ділянка НФаУ, вересень 2013 р.); RS 346 - серія 010915 (с. Рубіжне Харківської області, вересень 2015 р.); RS 351 - серія 060105 (м. Львів, ПП “Едель” від 31.01.2014 р.); RS 352 - серія 060913 (м. Харків, ТОВ аптека "Лікарські рослини", вересень 2013 р.); RS 353 - серія 070912 (фрармакопейна ділянка НФаУ, вересень 2012 р.); RS 354 - серія 180913 (с. Липці Харківської області, вересень 2013 р.); RS 355 - серія 111013 (фрармакопейна ділянка НФаУ, жовтень 2013 р.).

Вміст антоціанів у аронії чорноплідної плодах свіжих визначали методом абсорбційної спектрофоотометрії на спектрофоотометрі HP 8453 UV-VIS форми "Hewlett Packard" (США) згідно 3 уніфрікованою методикою, яку наведено в монограсрії ДФУ “Чорниці плоди, свіжі” [7]. Для цього 50 г аронії чорноплідної плодів свіжих розчавлювали безпосередньо перед випробуванням. До 5,00 г розчавленої сировини (точна наважка) додавали 95 мл метанолу Р, розмішували механічно протягом 30 хв, фрільтрували в мірну колбу місткістю 100,0 мл. Фільтр обполіскували і доводили об'єм розчину метанолом Р до 100,0 мл. Готували 50-кратне розведення цього розчину в розчині 0,1 \% (об/об) хлористоводневої кислоти Р у метанолі Р. Вимірювали оптичну густину (2.2.25) розчину за довжини хвилі 528 нм, вико- ристовуючи як компенсаційну рідину розчин 0,1 \% (об/об) хлористоводневої кислоти Р у метанолі Р. Вміст антоціанів, у відсотках, у перерахунку на ціанідин-3-О-глюкозиду хлорид обчислювали за фрормулою:

$$
X=\frac{A \cdot 5000}{718 \cdot m},
$$

де $A$ - оптична густина випробовуваного розчину за довжини хвилі 528 нм;

$m$ - маса наважки випробовуваної сировини, г;

718 - питомий показник поглинання ціанідин-3-О-глюкозиду хлориду.

Типовий спектр поглинання випробовуваних розчинів аронії чорноплідної плодів свіжих за довжини хвилі 528 нм, які одержано при визначенні вмісту антоціанів, наведено на рисунку 1 , результати дослідження - в таблиці 1.

Кількісне визначення танінів у аронії чорноплідної плодах висушених проводили методом абсорбційної спектрофотометрії при $\lambda=760$ нм, як зазначено у статті (2.8.14) ДФУ [8]. Для аналізу використовували 1,500 г здрібненої на порошок сировини (355) (2.9.12).

Типові спектри поглинання випробовуваних розчинів аронії чорноплідної плодів висушених і розчину порівняння пірогалолу за довжини хвилі 760 нм, які одержано при визначенні вмісту поліфенолів і танінів, наведено на рисунку 2 , результати дослідження - в таблиці 2.

РЕЗУЛЬТАТИ Й ОБГОВОРЕННЯ. ЯК свідчаТЬ результати дослідження, вміст антоціанів у аронії чорноплідної плодах свіжих становить від $(0,45 \pm 0,01)$ до $(0,56 \pm 0,02) \%$ у перерахунку на ціанідин-3-О-глюкозиду хлорид; вміст танінів у

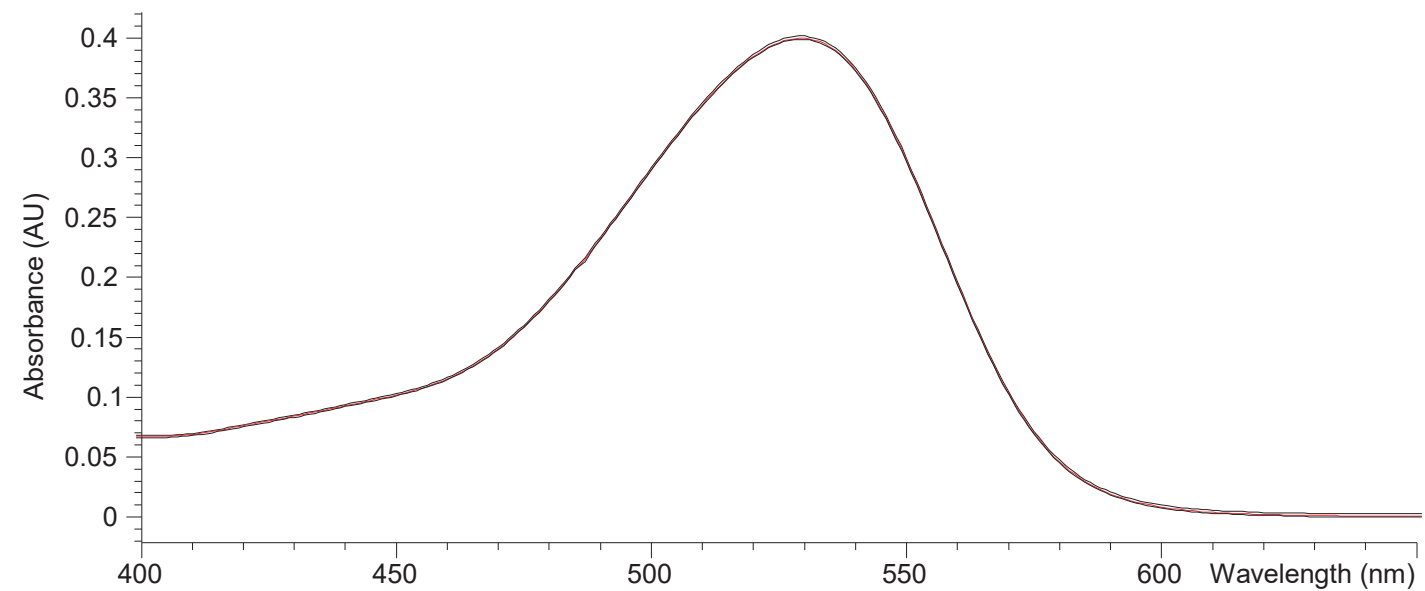

Рис. 1. Типовий спектр поглинання випробовуваних розчинів аронії чорноплідної плодів свіжих, які одержано при визначенні вмісту антоціанів у сировині.

Таблиця 1 - Вміст антоціанів у аронії чорноплідної плодах свіжих

\begin{tabular}{|c|c|c|c|c|c|c|c|}
\hline \hline \multirow{2}{*}{ Група БАР } & \multicolumn{7}{|c|}{ Вміст у зразках, \% } \\
\cline { 2 - 8 } & RS 338 & RS 339 & RS 340 & RS 341 & RS 342 & RS 343 & RS 344 \\
\hline Антоціани & $0,56 \pm 0,02$ & $0,49 \pm 0,01$ & $0,46 \pm 0,02$ & $0,50 \pm 0,03$ & $0,47 \pm 0,02$ & $0,45 \pm 0,01$ & $0,51 \pm 0,03$ \\
\hline
\end{tabular}




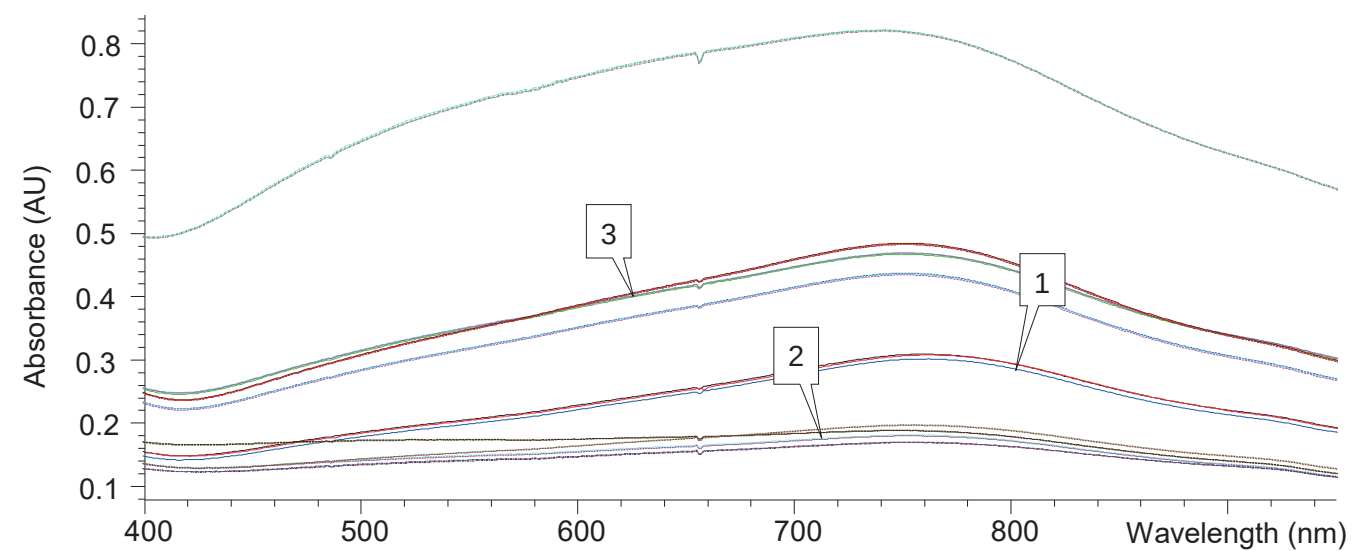

Рис. 2. Типові спектри поглинання випробовуваних розчинів аронії чорноплідної плодів висушених і розчину порівняння пірогалолу (1), які одержано при визначенні вмісту танінів (2) і полісренолів (3) у сировині.

Таблиця 2 - Вміст танінів і поліфенолів у аронії чорноплідної плодах висушених

\begin{tabular}{|l|c|c|c|c|c|c|c|}
\hline \multirow{2}{*}{ Група БАР } & \multicolumn{7}{|c|}{ Вміст у зразках, \% } \\
\cline { 2 - 8 } & RS 345 & RS 346 & RS 351 & RS 352 & RS 353 & RS 354 & RS 355 \\
\hline Таніни & $2,41 \pm 0,03$ & $1,73 \pm 0,01$ & $1,51 \pm 0,02$ & $1,84 \pm 0,04$ & $1,99 \pm 0,04$ & $2,35 \pm 0,05$ & $2,00 \pm 0,05$ \\
\hline Поліфеноли & $3,33 \pm 0,03$ & $2,91 \pm 0,04$ & $2,31 \pm 0,01$ & $3,01 \pm 0,03$ & $3,36 \pm 0,02$ & $3,08 \pm 0,07$ & $3,25 \pm 0,08$ \\
\hline
\end{tabular}

аронії чорноплідної плодах висушених - від $(1,51 \pm 0,02)$ до $(2,41 \pm 0,03) \%$ у перерахунку на пірогалол і суху сировину, поліфенолів - від $(2,31 \pm 0,01)$ до $(3,36 \pm 0,02) \%$.

До національної монограсрії "Аронії (гороби-

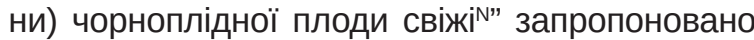
ввести показник: вміст антоціанів - не менше 0,40 \% у перерахунку на ціанідин-3-О-глюкозиду хлорид (хризантемін), а до національної монографії “Аронії (горобини) чорноплідної плоди

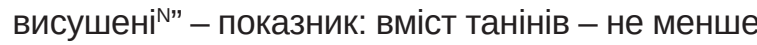
1,5 \% у перерахунку на пірогалол і суху сировину.

Результати досліджень використано при розробці національних монографрій "Аронії (горобини) чорноплідної плоди свіжі ${ }^{N}$ " й "Аронії (горобини) чорноплідної плоди висушені" [9].

\section{СПИСОК ЛІТЕРАТУРИ}

1. Криворучко О. В. Фармакогностичне дослідження представників родин Розові та Деренові як джерел одержання лікарських засобів : автореф. дис. на здобуття наук. ступеня д-ра фрармац. наук / О. В. Криворучко ; Нац. орармац. ун-т. - Х., 2016. - 40 с.

2. Aronia (Aronia melanocarpa) phenolics bioavailability in a combined in vitro digestion/Caco-2 cell model is structure and colon region dependent/ T. Wu, Ch. Grootaert, S. Voorspoels [et al.] // J. Funct. Foods. -2017. -38, Part A. - P. 128-139.

3. Котов А. Г. Фармакопейні аспекти стандартизації якості лікарської рослинної сировини і препаратів на її основі : автореф. дис. на здобуття наук. ступеня д-ра фрармац. наук / А. Г. Котов ; Нац. фрармац. ун-т. - Х., 2013. - 40 с.
ВИСНОВКИ. 1. Методом абсорбційної спектрофотометрії в аронії чорноплідної плодах свіжих визначено вміст антоціанів, у аронії чорноплідної плодах висушених - танінів.

2. Вміст антоціанів у аронії чорноплідної плодах свіжих становить від $(0,45 \pm 0,01)$ до $(0,56 \pm 0,02) \%$ у перерахунку на ціанідин-3-О-глюкозиду хлорид, вміст танінів у аронії чорноплідної плодах висушених - від $(1,51 \pm 0,02)$ до $(2,41 \pm 0,03) \%$ у перерахунку на пірогалол і суху сировину, поліфенолів - від $(2,31 \pm 0,01)$ до $(3,36 \pm 0,02) \%$.

3. Результати досліджень використано при розробці національних монографрій “Аронії (горобини) чорноплідної плоди свіжі "” й "Аронії (горобини) чорноплідної плоди висушені ${ }^{\text {”. }}$

4. Samoilova, V. A. Carboxylic acids from Aronia melanocarpa / V. A. Samoilova, V. N. Kovalev, V. A. Rybak, E. V. Krivoruchko // Chem. Nat. Compd. -2013. -49, No. 4. - P. 744-745.

5. Самойлова В. А. Проціанідини плодів аронії чорноплідної / В. А. Самойлова, О.В.Криворучко, В. М. Ковальов // Хімія природних сполук : матеріали IV Всеукр. наук.-практ. конфр. 3 міжнар. участю (Тернопіль, 21-22 квіт. 2016 р.). - Тернопіль : ТДМУ, 2016. C. 52 .

6. Котова Е. Е. Систематизація фрармакопейних вимог до методів контролю якості лікарської рослинної сировини. Уніфіковані спектрофотометричні методики / Е. Е. Котова, А. Г. Котов // Фармаком. - 2014. № 4. - C. 22-34. 
7. Державна Фармакопея України : в 3 т. / Держ. п-во "Український науковий фрармакопейний центр якості лікарських засобів". - 2-ге вид. - Х. : Держ. п-во "Український науковий фрармакопейний центр якості лікарських засобів", 2014. - Т. 3. - 732 с.

8. Державна Фармакопея України / Держ. п-во "Науково-експертний фрармакопейний центр". - 1-ше вид. - Допов. 2. - Х. : Держ. п-во “Науково-експертний фрармакопейний центр", 2008. - 620 с.

9. Державна Фармакопея України / Держ. п-во "Український науковий фрармакопейний центр якості лікарських засобів". -2-ге вид. - Допов. 1. - Х. : Держ. п-во "Український науковий фрармакопейний центр якості лікарських засобів", 2016. - 360 с.

\section{REFERENCES}

1. Kryvoruchko, O.V. (2016). Farmakohnostychne doslidzhennia predstavnykiv rodyn Rozovi ta Derenovi yak dzherel oderzhannia likarskykh zasobiv [The pharmacognostic study of plants of Rosaceae and Cornaceae families as sources of herbal drugs]. Doctor's Extended thesis. Kharkiv: Natsionalyi farmatsevtychnyi universytet [Ukrainian].

2. Wu, T., Grootaert, Ch., Voorspoels, S., Jacobs, G., Pitart, J., Kamiloglu, S., et al. (2017). Aronia (Aronia melanocarpa) phenolics bioavailability in a combined in vitro digestion/Caco-2 cell model is structure and colon region dependent. J. Funct. Foods, 38 (A), 128-139.

3. Kotov, A.H. (2013). Farmakopeini aspekty standartyzatsii yakosti likarskoi roslynnoi syrovyny i preparativ na yii osnovi [Pharmacopoeial aspects of the standardization of the quality of medicinal plant material and preparations on its basis]. Doctor's thesis. Kharkiv: Natsionalnyi farmatsevtychnyi universytet [in Ukrainian].

4. Samoilova, V.A., Kovalev, V.N., Rybak, V.A., \& Krivoruchko, E.V. (2013). Carboxylic acids from Aronia melanocarpa. Chem. Nat. Compd., 49 (4), 744-745.

5. Samoilova, V.A., Kryvoruchko, O.V., \& Kovaliov, V.M. (2016). Protsianidyny plodiv aronii chornoplidnoi [Procyanidins of fruit of Aronia melanocarpa]. Chemistry of Natural Compounds: Materials of IV Ukrainian Scientific Conference with international participation. Ternopil: TDMU [in Ukrainian].

6. Kotova, E.E., \& Kotov, A.H. (2014). Systematyzatsiia farmakopeinykh vymoh do metodiv kontroliu yakosti likarskoi roslynnoi syrovyny. Unifikovani spektrofotometrychni metodyky [Systematization of pharmacopoeial requirements for methods of quality control of medicinal plant raw materials. Uniform spectrophotometric techniques]. Farmakom., 4, 22-34 [in Ukrainian].

7. (2014). Ukrainian Scientific Pharmacopoeial Center for Quality of Medicines. State Pharmacopoeia of Ukraine [Державна Фармакопея Україна]. 2nd ed. Vol. 3. Kharkiv: Ukrainian Scientific Pharmacopoeial Center for Quality of Medicines [in Ukrainian].

8. (2008). Scientific Expert Pharmacopoeia Center. State Pharmacopoeia of Ukraine [Державна Фармакопея України]. 1.2 ed. Kharkiv: Scientific Expert Pharmacopoeia Center [in Ukrainian].

9. (2016). Ukrainian Scientific Pharmacopoeial Center for Quality of Medicines. State Pharmacopoeia of Ukraine. [Державна Фармакопея Україна]. 2.1 ed. Kharkiv: Ukrainian Scientific Pharmacopoeial Center for Quality of Medicines [in Ukrainian].

Е. В. Криворучко, А. Г. Котов ${ }^{1}$, В. А. Самойлова, Э. Э. Котова ${ }^{1}$, В. Н. Ковалев НАЦИОНАЛЬНЫЙ ФАРМАЦЕВТИЧЕСКИЙ УНИВЕРСИТЕТ, ХАРЬКОВ ГОСУДАРСТВЕННОЕ ПРЕДПРИЯТИЕ "УКРАИНСКИЙ НАУЧНЫЙ ФАРМАКОПЕЙНЫЙ ЦЕНТР КАЧЕСТВА ЛЕКАРСТВЕННЫХ СРЕДСТВ", ХАРЬКОВ

\section{ОПРЕДЕЛЕНИЕ СОДЕРЖАНИЯ АНТОЦИАНОВ И ТАНИНОВ В АРОНИИ ЧЕРНОПЛОДНОЙ ПЛОДАХ}

\section{Резюме}

Вступление. Арония черноплодная (Aronia melanocarpa) широко культивируется в Украине как пищевое, лекарственное и декоративное растение. Качество аронии черноплодной плодов свежих регламентировалось требованиями ФС 42-66-87 “Плоды аронии черноплодной (рябины черноплодной) свежие”, однако статью необходимо было пересмотреть с использованием современных подходов к стандартизации лекарственного растительного сырья. 
Цель исследования - определить содержание антоцианов и танинов в аронии черноплодной плодах свежих и высушенных для включения результатов исследований в раздел монографрии “Количественное определение".

Методы исследования. Содержание антоцианов и танинов в аронии черноплодной плодах свежих и высушенных определяли методом абсорбционной спектросротометрии.

Результаты и обсуждение. Содержание антоцианов в аронии черноплодной плодах свежих составляет от $(0,45 \pm 0,01)$ до $(0,56 \pm 0,02) \%$ в пересчете на цианидин-3-О-глюкозида хлорид, содержание танинов в аронии черноплодной плодах высушенных - om $(1,51 \pm 0,02)$ до $(2,41 \pm 0,03) \%$ в пересчете на пирогаллол и сухое сырье. Поэтому в национальную монограсрию "Аронии (рябины) черноплодной плоды свежие предложено ввести показатель: содержание антоцианов - не менее 0,40 \% в пересчете на цианидин-3-О-глюкозида хлорид, а в национальную монографию “Аронии (рябины) черноплодной плоды высушенные ${ }^{N "}$ - показатель: содержание танинов - не менее 1,5 \% в пересчете на пирогаллол и сухое сырье.

Вывод. Методом абсорбционной спектрофотометрии в аронии черноплодной плодах свежих определено содержание антоцианов, в аронии черноплодной плодах высушенных - танинов. Результаты исследований использовано при разработке национальных монографрий "Аронии (рябины) черноплодной плоды свежие ${ }^{N "}$ и “Аронии (рябины) черноплодной плоды высушенные ${ }^{N "}$.

КЛЮЧЕВЫЕ СЛОВА: арония черноплодная (Aronia melanocarpa); антоцианы; танины; полифенолы; стандартизация.

O. V. Krivoruchko, A. G. Kotov ${ }^{1}$, V. A. Samoilova, E. E. Kotova ${ }^{1}$, V. M. Kovalyov NATIONAL UNIVERSITY OF PHARMACY, KHARKIV STATE ENTERPRISE “UKRAINAN SCIENTIFIC PHARMACOPOEIAL CENTRE FOR QUALITY OF MEDICINES"', KHARKIV

\section{THE DETERMINATION OF CONTENT OF ANTHOCYANINS AND TANNINS IN FRUIT OF ARONIA MELANOCARPA}

Summary

Introduction. Aronia melanocarpa is widely cultivated in Ukraine as a food, medicinal and ornamental plant. The quality of fresh fruit of Aronia melanocarpa was regulated by the requirements of the pharmaceutical article 42-66-87 "Fresh fruit of Aronia melanocarpa", but the article required a revision using modern approaches to the standardization of medicinal plant material.

The aim of the study - determination of the content of anthocyanins and tannins in fresh and dried fruit of Aronia melanocarpa for inclusion the results of the research in the section of the monograph "Quantitative determination".

Research Methods. The determination of the content of anthocyanins and tannins in fresh and dried fruit of Aronia melanocarpa was carried out by the method of absorption spectrophotometry.

Results and Discussion. The content of anthocyanins in fresh fruit of Aronia melanocarpa is from $(0.45 \pm 0.01) \%$ to $(0.56 \pm 0.02) \%$ in terms of cyanidin-3-O-glucoside chloride, the content of tannins in dried fruit of Aronia melanocarpa is from $(1.51 \pm 0.02) \%$ to $(2.41 \pm 0.03) \%$ in terms of pyrogallol and dry raw materials. Therefore, we proposed to enter the indicator: the content of anthocyanins - at least $0.40 \%$ in terms of cyanidin-3-O-glucoside chloride to the national monograph "Fresh fruit of Aronia melanocarpa $\mathrm{N}^{\mathrm{N}}$, and the indicator: the content of tannins - not less than $1.5 \%$ in terms of pyrogallol and dry raw materials to the national monograph "Dried fruit of Aronia melanocarpa $^{N "}$.

Conclusion. By the method of absorption spectrophotometry in fresh fruit of Aronia melanocarpa the content of anthocyanins was determined, in dried fruit of Aronia melanocarpa - tannins. The results of the research were used during the development of the national monographs "Fresh fruit of Aronia melanocarpa" and "Dried fruit of Aronia melanocarpa ${ }^{\mathrm{N}}$.

KEY WORDS: Aronia melanocarpa; anthocyanins; tannins; polyphenols; standardization.

Отримано 10.01.18

Адреса для листування: О. В. Криворучко, Національний фрармацевтичний університет, вул. Валентинівська, 4, Харків, 61168, Україна, e-mail: evphyto@gmail.com. 